URNAL EXPLORE IT!

'ol. 10 No. 1 - Juni 2018

I-ISSN 2086-3489 (Print)- e-ISSN 2549-354X (Online)

ivaiable online at

nttp://jurnal.yudharta.ac.id/v2/index.php/EXPLORE-IT/

\title{
PERBANDINGAN METODE $k$-NN DAN NEURAL NETWORK (Backpropagation) DALAM KLASIFIKASI GIZI ANAK
}

\author{
${ }^{1}$ Arif Faizin, Purwanto, ${ }^{2}$ Catur Supriyanto \\ ${ }^{1,2}$ Program Magister Komputer Universitas Dian Nuswantoro Semarang \\ 1,2 Jl. Imam Bonjol No. 207, Semarang \\ ${ }^{1}$ E-mail : arifu_san@yahoo.co.id
}

\begin{abstract}
In the Decree of the Minister of Health of the Republic of Indonesia No. 1995 / Menkes / SK / XII / 2010 dated December 30, 2010 and the World Health Organization- National Center for Health Statistics (NCHSWHO), it is clear how standardization child nutrition is a very urgent matter. Because to know the nutritional intake of children that must be met when the condition of the child in a state of malnutrition or if the child nutrition. In this case, the child nutrition will affect brain development; adequate nutrition will be able to add to the absorption of the brain which will give the maximum intelligence, which corresponds to the opening 45 that is to educate intelligence UDD Nations children, which will be the focus point of this research. Methods to be used are two methods of data mining classification that Neural Network and K-Nearest Neighbor (K-NN), which will be sought method best of both methods, in seeking highest accuracy.
\end{abstract}

Keynotes: Child Nutrition, Neural Networks and K-Nearest Neighbor (K-NN),

\section{PENDAHULUAN}

Gizi bayi berarti memastikan bayi anda mendapat cukup nutrisi selama tahun pertamanya. Gizi adalah kalori, protein, lemak, vitamin, dan mineral. Pastikan bayi Anda memiliki gizi yang baik dapat melindungi dirinya terhadap penyakit. Hal ini juga membantu tetap sehat.Rekomendasi dari American Academy of Pediatrics Committee on Nutrition[1] mengenai praktek pemberian makanan bayi selama enam bulan kedua kehidupan. Rekomendasi tersebut menyebutkan bahwa menyusui adalah metode yang disukai dari makan selama tahun pertama kehidupan dan susu sapi yang keseluruhan yang dapat diperkenalkan setelah usia enam bulan jika menyusui tambahan yang memadai diberikan [2]. Memberian gizi yang cukup pada pada pada umur 6 bulan kedua atau secara detail pada umur 6bulan sampai 24 bulan atau ketika umur 2 tahun.

Keberhasilan pembangunan suatu bangsa ditentukan oleh ketersediaan sumber daya manusia (SDM) yang berkualitas, yaitu SDM yang memiliki fisik yang tangguh, mental yang kuat, kesehatan yang prima, serta cerdas. Bukti empiris menunjukkan bahwa hal ini sangat ditentukan oleh status gizi yang baik. Status gizi yang baik ditentukan oleh jumlah asupan pangan yang dikonsumsi. Masalah gizi kurang dan buruk dipengaruhi langsung oleh faktor konsumsi pangan dan penyakit infeksi. Secara tidak langsung dipengaruhi oleh pola asuh, ketersediaan pangan, faktor sosial ekonomi, budaya dan politik. Apabila gizi kurang dan gizi buruk terus terjadi dapat menjadi faktor penghambat dalam pembangunan nasional. Secara perlahan kekurangan gizi akan berdampak pada tingginya angka kematian ibu, bayi, dan balita, serta rendahnya umur harapan hidup. Selain itu, dampak kekurangan gizi terlihat juga pada rendahnya partisipasi sekolah, rendahnya pendidikan, serta lambatnya pertumbuhan ekonomi [3].

Kesepakatan global berupa Millenium Development Goals (MDGS) yang terdiri dari 8 tujuan, 18 target dan 48 indikator, menegaskan bahwa pada tahun 2015 setiap negara menurunkan kemiskinan dan kelaparan separuh dari kondisi pada tahun 1990. Untuk Indonesia, indikator yang digunakan adalah peresentase anak berusia di bawah 5 tahun (balita) yang mengalami gizi buruk (severe underweight) dan persentase anak-anak berusia 5 tahun (balita) yang mengalami gizi kurang (moderate underweight) [4].

Pada penelitian ini melakukan penelitian pada daerah probilinggo dengan melakukan pengumpulang data pada puskesmas, dari data tersebut melakukan klasifikasi pendataan tentang gizi anak pada daerah tersebut. Dalam bidang gizi, antropometri telah diaplikasikan secara luar dan detail untuk menilai status gizi masyarakat. Penilaian status gizi masyarakat daerah Probolinggo dengan antropmetri pada dasarnya adalah mengukur perubahan pertumbuhan anak yang mencakup pengukuran berat badan dan panjang badan atau tinggi badan dengan membandingkan hasil pengukuran dengan baku sesuai indeks yang digunakan. Dengan adanya standaritas untuk gizi anak yang memiliki kesesuian antara World Health Organization- National Center for Health Statistic (WHO-NCHS), yang memiliki Keputusan Menteri Kesehatan Republik Indonesia 
Nomor 1995/Menkes/SK/XII/2010 tanggal 30 Desember 2010 [8]]. Selama ini penentuan standarisasi gizi di daerah probolinggo belum dilakukan penelitian secaa detail, maka pada penelitian ini, peneliti melakukan penelitian penentuan standart gizi dengan menggunkan metode K-nn dan Neural Network untuk mengambil standar gizi yang akurat dengan metode yang telah disebutkan di atas.

Dengan menggunakan metode yang telah disebutkan di atas maka melakukan klasifikasi standart gizi pada daerah probolinggo berdasarkan data-data set yang telah didapatkan pada puskesmas Paiton Probolinggo. $k$-Nearest Neighbor $(k-\mathrm{NN})$ termasuk kelompok instance-based learning. Algoritma ini juga merupakan salah satu teknik lazy learning. $k$-NN dilakukan dengan mencari kelompok $k$ objek dalam data training yang paling dekat (mirip) dengan objek pada data baru atau data testing [9] $k$-NN kata lain dari tetangga terdekat, dimana metode ini akan mengklasifikasi data yang paling dekat atau mirip. Proses standarisasi gizi akan ditentukan sesuai dengan kedekatan atau kemiripan dari data satu ke data lainnya. Sedang metode Neural Nerwork merupakan sebuah mesin klasifikasi yang dimodelkan meniru dari struktur biologi pada saraf manusia [10]. Pendekatan metode ini, meniru kinerja saraf manusia, dimana akan melihat hubungan antara data satu dengan yang lainnya, yang mempunyai pengaruh secara ketergantungan. Secara umum model ini bekerja dengan menerima suatu vektor input I dan kemudian menghitung suatu respon atau output $\mathrm{O}$ dengan memproses (propagating) I melalui beberapa elemen-elemen proses yang saling terkait [10]. Dari kedua Data mining klasifikasi tersebut, akan diuji untuk mendapatkan pola atau model terbaik dalam menentukan klasifikasi penentuan standard gizi pada anak, yang antara umur 6 bulan sampai 24 bulan atau 2 tahun.

Dengan metode k-nn dan neural network melaksanakan penelitian pengklasifikasian standarisasi gizi anakpada derah Paiton Probolinggo dapat memetakan/mengelompokkan standarisasi setiap balita pada daerah Probolinggo berdasarkan standart yang diperoleh dari SK Mentri dan pendekatan metode k-nn dan neural network memudahkan standarisasi pengelompokan standarisasi gizi pada setiap balita

\subsection{Status Gizi}

\section{TINJAUAN PUSTAKA}

Status Gizi merupakan gambaran dari keadaan keseimbangan dalam bentuk variabel tertentu. Seperti contoh Gizi kurang merupakan keadaan tidak seimbangnya konsumsi makanan dalam tubuh seseorang. Status gizi ialah keadaan kesehatan individu-individu atau kelompok yang ditentukan oleh derajat kebutuhan fisik akan energi dan zat-zat gizi lain yang didapat dari makanan yang dampak fisiknya diukur secara antropometri [11].

Antropometri secara umum digunakan untuk melihat ketidakseimbangan asupan protein dan energi. Ketidakseimbangan ini terlihat pada pola pertumbuhan fisik dan proporsi jaringan tubuh seperti lemak, otot dan jumlah air dalam tubuh. Indikator antropometri yang umum digunakan untuk menilai status gizi balita adalah berat badan menurut umur $(\mathrm{BB} / \mathrm{U})$, tinggi badan menurut umur $(\mathrm{TB} / \mathrm{U})$, berat badan menurut tinggi badan $(\mathrm{BB} / \mathrm{TB})$.

Dalam pengukuran antropometri yang sering digunakan adalah BB/U karena mempunyai kelebihan yaitu lebih mudah dan lebih cepat dimengerti oleh masyarakat umum, baik untuk mengatur status gizi akut dan kronis, berat badan sangat sensitif terhadap perubahan-perubahan kecil, dan dapat mendeteksi kegemukan (over weight).

\subsubsection{Gizi Anak}

Masa yang terentang antara usia satu tahun sampai remaja boleh dikatakan sebagai periode laten karena pertumbuhan fisik berlangsung tidak sedramatis ketika masih berstatus bayi. Di tahun pertama kehidupan, panjang bayi bertambah sebanyak 50\%, tetapi tidak berlipat setelah usia bertambah sampai 4 tahun.

Anak yang berumur 1-3 tahun akan mengalami pertumbuhan berat sebanyak 2-2,5 kg, dan tinggi ratarata sebesar $12 \mathrm{~cm}$ setahun (tahun kedua $12 \mathrm{~cm}$, ketiga $8-9 \mathrm{~cm}$ ). Berat badan baku dapat pula mengacu pada baku berat badan dan tinggi badan dari WHO/NCHS, atau rumus perkiraan berat badan anak: Berat anak usia 1-6 tahun =[usia $\times 2+8]$. Dengan demikian, berat anak 1 sampai 3 tahun masing-masing 10, 12, dan $14 \mathrm{~kg}$.

Dengan baku WHO-NCHS, rata-rata berat anak usia 1,2 dan 3 tahun berturut-turut 10,2; 12,6; dan 14,7 $\mathrm{kg}$ untuk anak lelaki, sementara untuk anak perempuan 9,5; 11,9; dan 13,9 kg. Tinggi badan anak lelaki masing-masing 76,1; 87,6; dan 96,5 $\mathrm{cm}$. Tinggi badan anak perempuan berturut-turut 74,3;86,5; dan 95,6 $\mathrm{cm}$. Jika dibandingkan dengan tinggi badan yang dihitung dengan rumus, hasilnya tidak jauh berbeda [9].

Pertambahan berat anak usia prasekolah (dibatasi 4-6 tahun) berkisar antara 0,7-2,3 kg dan tinggi 0,9$1,2 \mathrm{~cm} /$ tahunnsehingga menyebabkan tubuh mereka tampak "kurus". Berat pada usia 7-10 tahun bertambah 
sekitar $2 \mathrm{~kg}$ dan tinggi badan 5-6 $\mathrm{cm}$ setiap tahun. Menjelang puber, pertambahan berat dapat mencapai 4$4,5 \mathrm{~kg}$ setahun.

Perkembangan mental anak dapat dilihat dari kemampuannya mengatakan "tidak" terhadap makanan yang ditawarkan. Penolakan itu tentu saja tidak boleh dijadikan alasan oleh para orang tua untuk memulai "perang di meja makan" karena ketegangan justru akan memicu dan memacu sikap yang lebih defensif. Ada baiknya diadakan kompromi, anak diberi pilihan satu atau dua macam makanan.

Pada banyak penelitian dilaporkan bahwa pada usia ini kebanyakan anak hanya mau makan satu jenis makanan selama berminggu-minggu (food jag). Orang tua tidak perlu gusa, asal makanan tersebut dapat memenuhi kebutuhan gizi anak. Sementara itu orang tua (atau pengasuh anak) tidak boleh jera menawarkan kembali jenis makanan lain setiap kali makan.

Tabel 2.2Rumus perkiraan berat badan

\begin{tabular}{|l|l|}
\hline Usia & Berat Badan $(\mathrm{kg})$ \\
\hline Lahir & 3,25 \\
\hline $3-12$ bulan & {$[$ usia (bl) +9$]: 2$} \\
\hline 1-6 tahun & {$[$ usia (th) 2 +8$]$} \\
\hline 6-12 tahun & {$[$ usia (th) x 7-5] : 2} \\
\hline
\end{tabular}

Tabel 2.3Rumus Perkiraan Tinggi badan

\begin{tabular}{|l|l|}
\hline Usia & Tinggi Badan $(\mathrm{cm})$ \\
\hline Lahir & 50 \\
\hline-1 tahun & 75 \\
\hline $2-12$ tahun & Usia (tahun ) x 6 +77 \\
\hline
\end{tabular}

(dikutip dari "Nelson textbook of pediatrics")

2.1.2 Masalah Gizi anak

Masalah gizi anak secara garis besar merupakan dampak dari ketidakseimbangan antara asupan dan keluaran gizi (nutritional imbalance), yaitu asupan yang melibihi keluaran atau sebaliknya, disamping kesalahan dalam memilih bahan makanan untuk disantap. Buah dari ketergangguan ini utamanya berupa penyakit kronis, berat badan lebih dan kurang, pica, karies dentis, serta alergi.

2.1.2.1 Penyakit Kronis

Penyakit yang tidak menguras cadangan energi sekalipun jika berlangsung lama dapat mengganggu pertumbuhan karena menghilangkan nafsu makan anak. Di samping itu, ada pula jenis penyakit yang menguras cadangan zat gizi, misalnya, campak yang menghabiskan cadangan vitamin A.

2.1.2.2 Berat Badan Lebih

Jika tidak teratasi, berat badan berlebih (apalagi jika telah mencapai obesitas) akan berlanjut sampai remaja dan dewasa. Sama seperti orang dewasa, kelebihan berat badan anak terjadi karena ketidakseimbangan antara energi yang masuk dan keluar,

2.1.2.3 Berat badan kurang

Kekurangan berat badan yang berlangsung pada anak yang sedang tumbuh merupakan masalah serius. Kondisi ini mencerminkan kebiasaan makan yang buruk. Sama seperti masalah kelebihan berat, langkah penanganan harus didasarkan pada penyebab serta kemungkinan pemecahannya. Pertanyaan berikut mungkin dapat menyaring penyebab, untuk kemudian mengupayakan penanganan: (1)Konsumsi makanan atau minuman apakah yang selalu membuatnya muntah atau diare?; (2) Apakah selalu ada makanan di rumah?; (3) Apakah anak sering tidak makan atau sarapan dan menggantinya dengan makanan yang mengandung kalori atau zat gizi rendah?; (4) Apakah anak makan satu jenis makanan saja dalam waktu lama?;(5) Apakah anak dapat tidur lelap?; (6) Apakah anak banyak menonton iklan makanan di televisi dan menirunya?; (7) Apakah waktu makan menjadi ajang yang membuat anak tegang? Semua ini dapat mengakibatkan anak enggan makan. Pemecahannya tentu saja dengan menghilangkan semua pertanyaan tersebut.

2.1.2.4 Pica

Orang yang mengkonsumsi sesuatu bukan makanan, misalnya perca dan debu, tergolong ke dalam pica. Perilaku tersebut tidak membahayakan hidup anak sejauh dia tidak menyantap zat toksik. Pica harus dibedakan dengan kebiasaan anak, terutama batita, memasukkan barang ke dalam mulut. Pada masa batita, anak menggunakan mulut untuk belajar, misalnya menggigit kelereng, dan ini bukan pica. 


\subsubsection{Penilaian Status Gizi}

Pada prinsipnya, penilaian status gizi anak serupa dengan penilaian pada periode kehidupan lain. Pemeriksaan yang perlu lebih diperhatikan tentu saja bergantung pada bentuk kelainan yang bertalian dengan kejadian penyakit tertentu. Kurang kalori protein, misalkan lazim menjangkiti anak. Oleh karena itu, pemeriksaan terhadap tanda dan gejala ke arah sana termasuk pula kelainan lain yang menyertainya, perlu dipertajam .

Anamnesis tentang asupan pangan yang terkait dengan baik status gizi maupun kesehatan gigi: asupan fluor baik secara sistematik maupun topikal; frekwensi ngemil (snacking); jumlah makanan yang disantapantara dua waktu makan; asupan minuman bergula, seperti jus, kopi, teh, dan soda; obat atau kondisi yang mempengaruhi sekresi air ludah (mengurangi atau menambah); penyakit kronik, misalnya gangguan makan, DM, HIV, atau penyakit jantung, mutu makanan yang disantap secara umum setiap hari; penggunaan suplementasi vitamin dan mineral; penggunaan botol (diisi susu atau jus buah, atau digunakan sekedar untuk ngempeng). Sebagian makanan bersifat protektif terhadap enamel sementara sisanya bertabiat merusak. Substansi yang berkemampuan mengurangi kepekaan enamel terhadap proses demineralisasi ialah flour, kokoa, fitat oksalat, dan protein susu. Jeruk sitrun diyakini merangsang sekresi air ludah; sementara berbagai obat, radioterapi kanker mulut dipastikan mereduksi pengaliran saliva.

Anamsesis juga wajib mencantumkan pola konsumsi obat karena kemungkinan interaksi antara makanan dan obat. Obat (baik yang diperoleh dengan resep dokter maupun dibeli sendiri) berpotensi mengganggu pencernaan, penyerapan, metabolisme, utilisasi, serta eksresi berbagai zat gizi. Obat bahkan memiliki kehandalan dalam mengganggu status gizi, sehingga berat badan pengguna beberapa obat tertentu merosot, disamping terkondisi pula untuk menjadi anoreksia. Antasida berbasis alumunium dan magnesium hidroksida yang digunakan dalam dosis tinggi, misalnya akan menguras cadangan fosfat sedemikian rupa sehingga kekurangan fosfat kemudian mendapat tempat. Dari sini kelemahan otot, anoreksia, dan gagal jantung kongestif gampang sekali muncul. Sebaliknya, tidak sedikit zat (status) gizi yang juga berkemampuan mempengarui kerja obat dengan jalan mengubah alur metabolisme dan fungsi obat; disamping zat gizi itu sendiri juga memiliki khasiat farmokologi pada keadaan tertentu. Sebagai contoh, kebutuhan akan vitamin A meningkat oleh konsumsi bersama dengan anti kejang (phenytoin) dan antikolesterol (cholesteyalmine). Kebutuhan akan vitamin D juga meningkat oleh keberadaan obat pengikat asam empedu (colestipol). Kebutuhan akan vitamin $\mathrm{K}$ juga bertambah oleh phenytoin. Kadar karoten dipengaruhi oleh pil KB, dan anti kejang. Kadar vitamin $\mathrm{B}_{6}$ dan $\mathrm{B}_{12}$ juga berkurang oleh pil KB.

Pemeriksaan klinis diarahkan untuk mencari kemungkinan adanya bintik bitot, xerosis konjungtiva, anemia, pembesaran kelenjar parotis, kheilosis angular, fluorosis, karies, gondok, serta hepato dan splenomegali.

Penilaian antropometris yang penting dilakukan adalah penimbangan berat dan pengukuran tinggi badan, lingkar lengan, dan lipatan kulit triseptis. Pemeriksaan ini penting, terutama pada anak prasekolah yang berkelas ekonomi dan sosial rendah. Pengamatan anak usia sekolah dipusatkan terutama pada percepatan tumbuh. Uji pertumbuhan pada golongan usia ini setidaknya diselenggarakan setahun sekali karena laju pertumbuhan pada fase ini relatif lambat. Sebagai patokan, pertambahan berat anak usia 5-10 tahun berkisar sampai 10\% nya, sementara tinggi badan hanya bertambah sekitar $2 \mathrm{~cm}$ setahun.

Uji biokimiawi yang penting adalah pemeriksaan kadar hemoglobin, serta pemeriksaan occult blood dan telur cacing saja.

2.2 Algoritma k-Nearest Neighbor

Algoritma K-NN adalah metode yang menggunakan algoritma supervised[16]. Perbedaan antara supervised learning dengan unsupervised learning adalah pada supervised learning bertujuan untuk menemukan pola baru dalam data dengan menghubungkan pola data yang sudah ada dengan data yang baru. Sedangkan pada unsupervised learning untuk menemukan pola dalam sebuah data.

Tujuan dari algoritma $k$-NN adalah untuk mengklasifikasikan objek baru berdasarkan atribut dan training samples[17] Dimana hasil dari sampeluji yang baru diklasifikasikan berdasarkan mayoritas dari katergori pada $k$-NN. Pada proses pengklasifikasian, algoritman ini tidak menggungakan model apapun untuk dicocokkan dan hanya berdasarkan pada memori. Algoritma $k$-NN menggunakan klasifikasi ketetanggan sebagai nilai prediksi dari sampel uji yang baru. Jarak yang digunakan adalah jarak Euclidean Distance. Jarak Euclidean adalah jarak yang paling umum digunakan pada data numerik[18]. 
Euclidean distance didefinisikan sebagai berikut :

$$
d\left(x_{i}, x_{j}\right)=\sqrt{\sum_{r}^{n}=1\left(a_{r}\left(x_{i}\right)-a_{r}\left(x_{j}\right)\right)^{2}}
$$

Keterangan:

$d\left(x_{i}, x_{j}\right) \quad:$ Jarak data uji ke dataset training (Euclidean Distance)

$\left(x_{i}\right) \quad:$ record ke- $i$

$\left(x_{j}\right) \quad:$ record ke- $j$

$\left(a_{r}\right) \quad$ : data ke- $r$

ij $\quad: 1,2,3, \ldots \ldots . n$

2.3 Algoritma Neural Network

Dalam peneyelesaian tesis ini peneliti menggunakan logika Algoritma Neural Network dengan metode backpropagation. Dalam metode Algoritma BackPropagationmenerapkan aturan generalisasi delta (Widrow-Hoff), yaitu metode yang menerapkan gradient descent untuk meminimalkan error kuadrat total dari keluaran yang dihitung oleh jaringan. Adapun arsitektur dari analisis algoritma menggunakan metode Neural network backpropagation adalah seperti gambar di bawah ini :

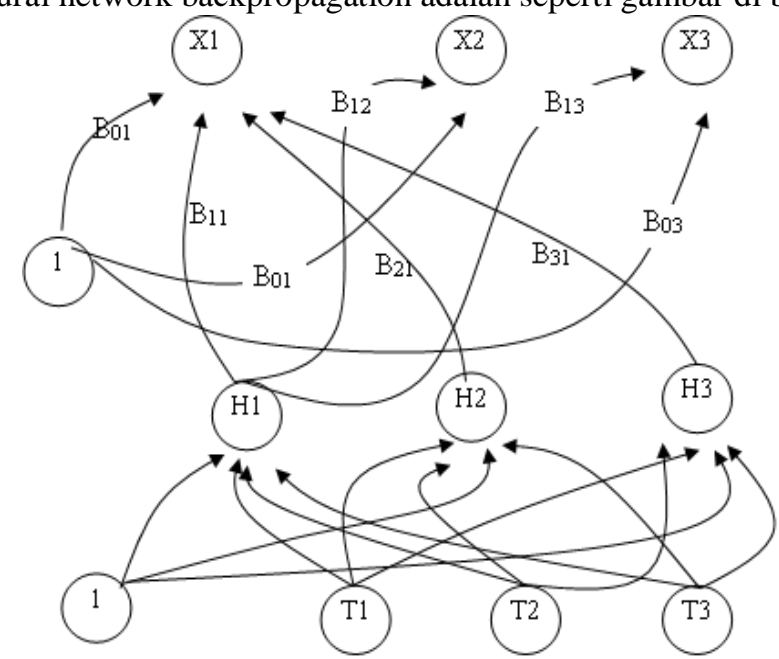

Gambar 2.1 arsitektur algoritma backpropagation

Jaringan algoritma Neural Network dengan metode backpropagation mempunyai inputan layer (unit $\mathrm{X}(\mathrm{X} 1, \mathrm{X} 2, \mathrm{X} 3)$ kemudian satu layer tersembunyi (unit $\mathrm{H}\left(\mathrm{H}_{1}, \mathrm{H} 2, \mathrm{H} 3\right)$ seperti ditunjukkan pada gambar di atas memiliki unit keluaran (unit T(T1, T2, T3) dan hidden layer memiliki bias 1.

Fungsi aktivasi dari algoritma neural network backpropagation seperti yang ditunjukkan pada gambar di bawah ini :

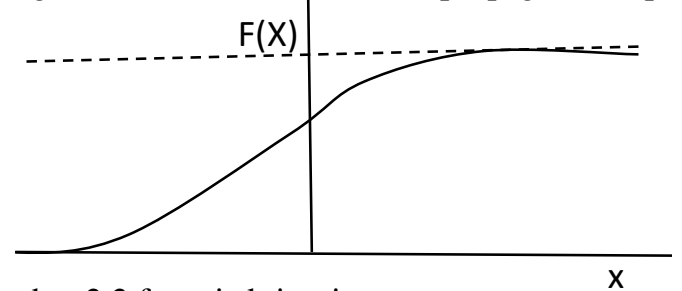

Gambar 2.2 fungsi aktivasi

Rumus aktivasi sigmoid biner dengan range 0,1

$F(x)=1 /\left(1+e^{x}\right)$ dengan turunan $\mathrm{f}^{\prime}(\mathrm{x})=\mathrm{f}(\mathrm{x})(1-\mathrm{f}(\mathrm{x}))$ 
Adapun aktivasi sigmoid bipolar dari algoritma neural network backpropogation adalah seperti ditunjukkan pada gambar di bawah ini :

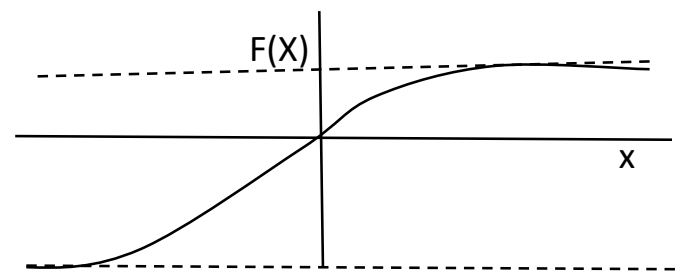

Gambar 2.3 Rumus aktivasi sigmoid bipolar dengan range $(-1,1)$

$\mathrm{F}(\mathrm{x})=\left(2 /\left(1+\mathrm{e}^{\mathrm{x}}\right)\right)-1$ dengan turunan $\mathrm{f}^{\prime}(\mathrm{x})=1 / 2(1+\mathrm{f}(\mathrm{x}))(1-\mathrm{f}(\mathrm{x}))$

Adapun Algoritma penyelesaian backpropogation satu hidden layer dengan aktivasi sigmoid biner adalah sebagai berikut :

1. Inisialisasi semua bobot dengan bilangan acak kecil

2. Jika kondisi henti belum terpenuhi, lakukan langkah $2-9$

3. Untuk setiap pasangan data pelatihan, lakukan langkah $3-8$

\section{Fase I Propagasi Maju}

4. Tiap unit masukan menerima sinyal dan meneruskan ke unit tersembunyi di atasnya

5. Hitung semua keluaran di unit tersembunyi $\mathrm{Zj}(\mathrm{j}=1 \ldots . \mathrm{p})$

$$
\begin{aligned}
& \mathrm{z}_{\text {_net } \mathrm{j}}=\mathrm{v}_{0 \mathrm{j}}+\Sigma=\text { pjijivx } 1 \\
& \mathrm{z}_{\mathrm{j}}=\mathrm{f}(\mathrm{z} \text { _net } \mathrm{j}
\end{aligned}
$$

6. Hitung semua keluaran jaringan di unit $\mathrm{Y}_{\mathrm{k}}(\mathrm{k}=1 \ldots \mathrm{m})$

$$
\begin{aligned}
& \mathrm{y}_{\text {nnet } \mathrm{k}}=\mathrm{w}_{0 \mathrm{j}}+\Sigma=m k j k j w z 1 \\
& \mathrm{y}_{\mathrm{k}}=\mathrm{f}\left(\mathrm{y}_{\text {nnet } \mathrm{k}}\right)=k_{-} n e t \_y e^{-+11}
\end{aligned}
$$

Fase II Propagasi Mundur

7. Hitung faktor $\delta$ unit keluaran berdasarkan kesalahan di setiap unit keluaran $\mathrm{Yk}(\mathrm{k}=1,2, \ldots, \mathrm{m})$

$\delta_{\mathrm{k}}=\left(\mathrm{t}_{\mathrm{k}}-\mathrm{y}_{\mathrm{k}}\right) \mathrm{f}^{\prime}\left(\mathrm{y}_{\text {net }}\right)=\left(\mathrm{t}_{\mathrm{k}}-\mathrm{y}_{\mathrm{k}}\right) \mathrm{y}_{\mathrm{k}}\left(1-\mathrm{y}_{\mathrm{k}}\right)$

$\delta_{\mathrm{k}}$ merupakan kesalahan yang akan dipakai dalam perubahan bobot layer dibawahnya

2.4 Validasi menggunakan Cross Validation

Cross Validation adalah satu cara menemukan parameter terbaik dari satu model dengan cara menguji besarnya error pada data test. Dalam cross validation, kita bagi data ke dalam $k$ sampel dengan ukuran yang sama. Kita gunakan $k-1$ sampel untuk training dan 1 sampel sisanya untuk testing. Ini sering disebut dengan validasi $k$-fold. Misalkan ada 10 subset data, kita menggunakan 9 subset untuk training dan 1 subset sisanya untuk testing. Ini dilakukan untuk semua kemungkinan. Ada 10 kali training dimana pada masing-masing training ada 9 subset data untuk training dan 1 subeset digunakan untuk testing. Dari situ lalu dihitung ratarata error dan standar devisiasi error[19].

Jika kita mempunyai 3 model, maka masing-masing model dicoba 10 kali pada setiap kombinasi trainingtesting subset dan setiap satu running akan ditemukan error untuk data testing. Setelah ketiga model dicoba akan diperoleh rata-rata dan standard devisiasi error untuk setiap model. Model yang memberikan rata-rata error terkecil adalah model yang terbaik.

\subsection{Evaluasi dengan menggunakan Confusion Matrix}

Confusion matrix adalah alat (tools) visualisasi yang biasa digunakan pada supervised learning. Tiap kolom pada matriks adalah contoh kelas prediksi, sedangkan tiap baris mewakili kejadian di kelas yang sebenarnya[20]. Metode ini hanya menggunakan table matriks seperti pada tabel berikut ini :

Tabel 2.4 Tabel Confusion Matrix

\begin{tabular}{|c|c|c|}
\hline Correct & \multicolumn{2}{|c|}{ Classified as } \\
\cline { 2 - 3 } Classification & + & False negative \\
\hline+ & True positive & True negative \\
\hline- & False positive &
\end{tabular}

Jika dataset hanya terdiri dari dua kelas, kelas yang satu dianggap sebagai positif dan yang lainnya negatif[21]. Evaluasi dengan confusion matrix menghasilkan nilai accuracy, precision, dan recall. 
Accuracy dalam klasifikasi adalah persentase ketepatan record data yang diklasifikasikan secara benar setelah dilakukan pengujian pada hasil klasifikasi[17]. Sedangkan precision atau confidence adalah proporsi kasus yang diprediksi positif yang juga positif benar pada data yang sebenarnya. Recall atausensitivity adalah proporsi kasus positif yang sebenarnya diprediksi positif secara benar.

True positive adalah jumlah record positif yang diklasifikasikan sebagai positif, false positive adalah jumlah record negative yang diklasifikasikan sebagai positif, false negative adalah jumlah record positif yang diklasifikasikan sebagai negative, kemudian masukkan data uji. Setelah data uji dimasukkan ke dalam confusion matrix, hitung nilai-nilai yang telah dimasukkan tersebut untuk dihitung jumlah sensitivity (recall), specifity, precision, dan accuracy. Sensitivity digunakan untuk membandingkan jumlah $t$ pos terhadap jumlah record yang positif sedangkan Specifity, precision adalah perbandingan jumlah t_neg terhadap jumlah record yang negative. Untuk menghitung digunakan persamaan di bawah ini [17].

$$
\begin{aligned}
& \text { Sensitifity }=\frac{t_{-} p o s}{\text { pos }} \\
& \text { Specifity }=\frac{t_{-} \text {neg }}{n e g} \\
& \text { Precision }=\frac{t_{-} \text {pos }}{t_{-} \text {pos }+f_{-} p o s} \\
& \text { Accuracy }=\text { Sensitivity } \frac{\text { pos }}{(\text { pos }+ \text { neg })}+\text { Specifity } \frac{\text { neg }}{(\text { pos }+n e g)}
\end{aligned}
$$

Keterangan :
t_pos : Jumlah true positive
t_neg : Jumlah true negative
$p$ : Jumlah record positive
$n$ : Jumlah tupel negative
f_pos : jumlah falsepositive

tabel berikut ini memperlihatkan tingkat accuracy, precision, dan recall hasil klasifikasi pada data training dan testing hasil pengujian dengan confusion matrix.

Tabel 2.5 hasil pengujian dengan confusion matrix

\begin{tabular}{|l|c|c|c|}
\hline & Data training & $\begin{array}{l}\text { Data } \\
\text { testing }\end{array}$ & $\begin{array}{l}\text { Hasil } \\
\text { Kompensasi }\end{array}$ \\
\hline Accuracy & $98,75 \%$ & $93,75 \%$ & $97,75 \%$ \\
\hline Precision & $92,31 \%$ & $62,50 \%$ & $86,35 \%$ \\
\hline Recall & $57,14 \%$ & $71,43 \%$ & $60 \%$ \\
\hline
\end{tabular}

\section{METODE PENELITIAN}

\subsection{Pengumpulan Data}

Penelitian ini memakai data gizi anak dari puskesmas paiton yang memiliki kesesuian dengan Keputusan Menteri Kesehatan Republik Indonesia Nomor 1995/ Menkes/ SK/ XII/ 2010 tanggal 30 Desember 2010, yang bertujuan mencari pola terbaik dari dua metode data mining.

Data set terdiri dari umur anak, berat badan, tinggi badan, status anak, dimana konversi sebagai berikut

Table 3.1 Variable Konversi

\begin{tabular}{|l|l|l|}
\hline \multicolumn{1}{|c|}{ Variable } & \multicolumn{1}{c|}{ Keterangan } & \multicolumn{1}{c|}{ Konversi } \\
\hline Umur anak & Bulan & X1 \\
\hline Berat badan & Kilogram $(\mathrm{Kg})$ & $\mathrm{X} 2$ \\
\hline Tinggi Badan & Centimeter $(\mathrm{Cm})$ & $\mathrm{X} 3$ \\
\hline Status Anak & Keterangan Gizi & $\mathrm{Y}$ \\
\hline
\end{tabular}

Maka hasil dari data set, dari standarisasi pada gizi anak sebagai berikut:

Tabel 3.2 Variable X dan Y pada Gizi Anak

\begin{tabular}{|c|c|c|c|}
\hline $\mathbf{X 1}$ & $\mathbf{X 2}$ & $\mathbf{X 3}$ & $\mathbf{Y}$ \\
\hline 6 & 5.7 & 61.2 & Gizi Buruk \\
\hline 6 & 6.4 & 63.3 & Gizi Kurang \\
\hline
\end{tabular}




\begin{tabular}{|c|c|c|l|}
\hline 6 & 7.1 & 65.5 & Gizi Kurang \\
\hline 6 & 7.9 & 67.6 & Gizi Baik \\
\hline 6 & 8.8 & 69.8 & Gizi Baik \\
\hline 6 & 9.8 & 71.9 & Gizi Baik \\
\hline 6 & 10.9 & 74 & Gizi Lebih \\
\hline 7 & 5.9 & 62.7 & Gizi Buruk \\
\hline 7 & 6.7 & 64.8 & Gizi Kurang \\
\hline 7 & 7.4 & 67 & Gizi Kurang \\
\hline
\end{tabular}

Penelitian ini memakai data-data standart gizi anak, yang peneliti dapat dari dari ibu Ike Aprilia P, Dokter yang menangani gizi pada anak, di Puskesmas Paiton Probolinggi Jawa Timur.

\subsection{Pendekatan/Usulan}

\subsubsection{Penjabaran metode yang dipakai}

Tahapan metode dalam penelitian ini adalah :

1. Penerapan metode yang pertama yaitu $k-\mathrm{NN}$

2. Penerapan metode yang kedua yaitu Neural Network

3. Validasi menggunakan $X$ - cross validation

4. Evaluasi menggunakan confusion matrix

\subsubsection{Eksperimen}

\section{Klasifikasi dengan menggunakan metode $k$-NN}

Adapun langkah-langkah untuk menghitung metode Algoritma K-Nearest Neighbor adalah sebagai berikut:

1. Menentukan Parameter Ranking tiap Attribut

2. Menentukan bobot tiap atribut

3. Menentukan ranking variabel tiap atribut

4. Menentukan bobot variabel tiap atribut

2. Klasifikasi dengan menggunakan metode Neural Network

Neural Network, disebut juga dengan suatu sistem pengelolah informasi yang memiliki karakteristik menyerupai jaringan saraf manusia. Neural Network berusaha meniru struktur/arsitektur dan cara kerja otak manusia sehingga mampu menggantikan beberapa pekerjaan manusia. Pekerjaan seperti mengenali pola (pattern recognition), prediksi, klasifikasi, pendekatan fungsi, optimasi adalah pekerjaan-pekerjaan yang diharapkan bisa diselesaikan dengan Neural Network.

Neural Netwok mempunyai beberapa kelebihan seperti kemampuan menyelesaikan pekerjaan prediksi yang polanya nonlinier, waktu penyelesaian yang cepat. Tidak mengherankan banyak pekerjaan dalam dunia nyata dilakukan dengan memanfaatkan Neural Network seperti dalam peramalan curah hujan, pendeteksian tornado, pendeteksian pemalsuan pemakaian kartu kredit.

Berikut ini adalah model komputasi untuk Neural Network. Model ini menghitung jumlah dari $n$ signal input $x_{j, j}=1,2, \ldots n$ yang diberi bobot dan menghasilkan nilai 1 bila jumlah tersebut di atas batas tertentu dan 0 bila di bawah batas tersebut. Secara matematis bisa ditulis sebagai berikut :

$y=\varphi\left(\sum_{j}^{n} w_{j} x_{j}-u\right)$

Dimana $\oplus$ adalah fungsi aktivasi dan $w$ adalah bobot sesuai dengan input ke-j.

3. Validasi dengan Cross $\mathbf{X}$ falidation

Cross validation merupakan sebuah tindakan pembuktian dari sebuah metode atau performa suatu algoritma. Dalam proses pengujian data mining yang paling banyak digunakan adalah cross validation. Cross validation merupakan pembuktian dengan membagi data sebagian sebagai data training dan sebagian yang lain sebagai data testing dengan komposisi tertentu. Pembagian paling banyak digunakan dalam penelitian klasifikasi data mining adalah membagi data secara acak menjadi 10 bagian. Satu bagian menjadi data testing dan 9 bagian dijadikan data training. Validasi yang seperti ini disebut juga dengan 10folds cross validation 
URNAL EXPLORE IT!

'ol. 10 No. 1 - Juni 2018

I-ISSN 2086-3489 (Print)- e-ISSN 2549-354X (Online)

Ivaiable online at

nttp://jurnal.yudharta.ac.id/v2/index.php/EXPLORE-IT/

\section{Evaluasi dengan Confusion matrix}

Confusion Matrix merupakan sebuah hasil evaluasi dari sebuah klasifikasi data mining yang diwujudkan dalam sebuah tabel. Confusion Matrix berisi tentang perhitungan jumlah objek data testing yang diprediksikan kedalam sebuah kelas dengan sebenarnya. Untuk menghitung akurasi sebuah algoritma dengan menggur 25 asi yang matrix dapat digunakan rumus sederhana berikut:

$$
\text { Accuracy }=\frac{\text { Klasifikasi yang sesuai }}{\text { total record yang ada }}
$$

\section{HASIL PENELITIAN DAN PEMBAHASAN}

\subsection{Hasil Penelitian}

4.1.1 Klasifikasi dengan Metode $k$-NN

Dalam penentuan metode k-NN memiliki tabel ketetapan untuk menentukan peringkat. Adapun tabel ketetapan peringkat seperti ditunjukkan pada tabel berikut :

Tabel 4.1 Derajat Kepentingan

\begin{tabular}{|l|c|c|}
\hline No & Nilai & Bobot Kepentingan \\
\hline 1 & 100 & 1 \\
\hline 2 & 90 & 2 \\
\hline 3 & 80 & 3 \\
\hline 4 & 70 & 4 \\
\hline 5 & 60 & 5 \\
\hline 6 & 50 & 6 \\
\hline 7 & 40 & 7 \\
\hline 8 & 30 & 8 \\
\hline 9 & 20 & 9 \\
\hline 10 & 10 & 10 \\
\hline
\end{tabular}

Sumber: $\quad$ Ayhan, M. B. 2013. A Fuzzy AHP Approach for Supplier Selection Problem

Adapun tahapan dalam metode k-NN adalah sebagai berikut :

1. Menentukan ranking ini bersifat subyektif, dalam penelitian ini penentuan ranking berdasarkan nilai pada tabel berikut ini:

Tabel 4.2 ranking atribut

\begin{tabular}{|r|r|l|l|}
\hline \multicolumn{1}{|c|}{ No } & Atribut & Ranking & Nilai \\
\hline 1 & Umur & 3 & 80 \\
\hline 2 & Berat & 1 & 100 \\
\hline 3 & Tinggi & 2 & 90 \\
\hline
\end{tabular}

2. Menentukan bobot tiap atribut

$$
w_{j}=\frac{\left(n-r_{j}+1\right)}{\sum\left(n-r_{p}+1\right)}
$$

a. Bobot Umur

$w_{u}=\frac{(3-3+}{(3-3+1)+(3-2+} \quad \frac{1}{i-1+1)}=\frac{1}{3}=0,33$

b. Bobot Berat

$w_{b}=\frac{(3-1+1)}{(3-3+1)+(3-2+1)+(3-1+1)}=\frac{3}{3}=1$

c. Bobot Tinggi

$w_{t}=\frac{(3-2+1)}{(3-3+1)+(3-2+1)+(3-1+1)}=\frac{2}{3}=0,66$

Tabel 4.3 bobot atribut

\begin{tabular}{|r|r|l|l|l|}
\hline \multicolumn{1}{|c|}{ No } & Atribut & Ranking & \multicolumn{1}{|c|}{ Nilai } & \multicolumn{1}{c|}{ Bobot } \\
\hline 1 & Umur & 3 & 80 & 0.33 \\
\hline 2 & Berat & 1 & 100 & 1 \\
\hline
\end{tabular}


URNAL EXPLORE IT!

/ol. 10 No. 1 - Juni 2018

I-ISSN 2086-3489 (Print)- e-ISSN 2549-354X (Online)

Ivaiable online at

nttp://jurnal.yudharta.ac.id/v2/index.php/EXPLORE-IT/

\begin{tabular}{l|l|l|l|l|}
3 & Tinggi & 2 & 90 & 0.66 \\
\hline
\end{tabular}

3. Menentukan ranking variabel tiap attribut, ini juga bersifat subyektif, dalam penelitian ini penentuan ranking tertera sebagai berikut :

Tabel 4.4 ranking umur

\begin{tabular}{|r|c|l|c|}
\hline No & Kriteria umur (tahun) & Nilai & Ranking \\
\hline 1 & $6-9$ & 100 & 1 \\
\hline 2 & $10-13$ & 90 & 2 \\
\hline 3 & $14-17$ & 80 & 3 \\
\hline 4 & $18-21$ & 70 & 4 \\
\hline 5 & $22-24$ & 60 & 5 \\
\hline
\end{tabular}

4. Menentukan bobot tiap atribut

$w_{j}=\frac{\left(n-r_{j}+1\right)}{\sum\left(n-r_{p}+1\right)}$

a. Bobot umur 6-9

$w 1=\frac{(5-1+1)}{(5-5+1)+(5-4+1)+(5-3+1)+(5-2+1)+(5-1+1)}=\frac{5}{15}=0,33$

b. Bobot umur 10-13

$w 2=\frac{(5-2+1)}{(5-5+1)+(5-4+1)+(5-3+1)+(5-2+1)+(5-1+1)}=\frac{4}{15}=0,26$

c. Bobot umur 14-17

$w 3=\frac{(5-3+1)}{(5-5+1)+(5-4+1)+(5-3+1)+(5-2+1)+(5-1+1)}=\frac{3}{15}=0,2$

d. Bobot umur 18-21

$w 4=\frac{(5-4+1)}{(5-5+1)+(5-4+1)+(5-3+1)+(5-2+1)+(5-1+1)}=\frac{2}{15}=0,13$

e. Bobot umur 22-24

$w 5=\frac{(5-5+1)}{(5-5+1)+(5-4+1)+(5-3+1)+(5-2+1)+(5-1+1)}=\frac{1}{15}=0,06$

Tabel 4.5 bobot umur

\begin{tabular}{|r|c|l|c|c|}
\hline No & Kriteria umur & Nilai & Ranking & Bobot \\
\hline 1 & $6-9$ & 100 & 1 & 0,33 \\
\hline 2 & $10-13$ & 90 & 2 & 0,26 \\
\hline 3 & $14-17$ & 80 & 3 & 0,2 \\
\hline 4 & $18-21$ & 70 & 4 & 0,13 \\
\hline 5 & $22-24$ & 60 & 5 & 0,06 \\
\hline
\end{tabular}

Tabel 4.6 ranking berat

\begin{tabular}{|r|c|l|c|}
\hline No & Kriteria Berat $(\mathrm{kg})$ & Nilai & Ranking \\
\hline 1 & $5-8$ & 100 & 1 \\
\hline 2 & $9-12$ & 90 & 2 \\
\hline 3 & $13-16$ & 80 & 3 \\
\hline 4 & $17-21$ & 70 & 4 \\
\hline
\end{tabular}

$w_{j}=\frac{\left(n-r_{j}+1\right)}{\sum\left(n-r_{p}+1\right)}$ 
a. Bobot berat 5-8

$w 1=\frac{(4-1+1)}{(4-4+1)+(4-3+1)+(4-2+1)+(4-1+1)}=\frac{4}{10}=0,4$

b. Bobot berat 9-12

$w 2=\frac{(4-2+1)}{(4-4+1)+(4-3+1)+(4-2+1)+(4-1+1)}=\frac{3}{10}=0,3$

c. Bobot umur 13-16

$w 3=\frac{(4-3+1)}{(4-4+1)+(4-3+1)+(4-2+1)+(4-1+1)}=\frac{2}{10}=0,2$

d. Bobot umur 17-21

$w 4=\frac{(4-4+1)}{(4-4+1)+(4-3+1)+(4-2+1)+(4-1+1)}=\frac{1}{10}=0,1$

Tabel 4.7 tabel bobot berat

\begin{tabular}{|r|c|l|c|c|}
\hline No & Kriteria Berat $(\mathrm{kg})$ & Nilai & Ranking & Bobot \\
\hline 1 & $5-8$ & 100 & 1 & 0,4 \\
\hline 2 & $9-12$ & 90 & 2 & 0,3 \\
\hline 3 & $13-16$ & 80 & 3 & 0,2 \\
\hline 4 & $17-21$ & 70 & 4 & 0,1 \\
\hline
\end{tabular}

Tabel 4.8 ranking tinggi

\begin{tabular}{|r|c|l|c|}
\hline \multicolumn{1}{|c|}{ No } & Kriteria Tinggi $(\mathrm{cm})$ & Nilai & Ranking \\
\hline 1 & $61-69$ & 100 & 1 \\
\hline 2 & $70-78$ & 90 & 2 \\
\hline 3 & $79-87$ & 80 & 3 \\
\hline 4 & $88-97$ & 70 & 4 \\
\hline
\end{tabular}

$w_{j}=\frac{\left(n-r_{j}+1\right)}{\sum\left(n-r_{p}+1\right)}$

a. Bobot Tinggi 61-69

$w 1=\frac{(4-1+1)}{(4-4+1)+(4-3+1)+(4-2+1)+(4-1+1)}=\frac{4}{10}=0,4$

b. Bobot Tinggi $70-78$

$w 2=\frac{(4-2+1)}{(4-4+1)+(4-3+1)+(4-2+1)+(4-1+1)}=\frac{3}{10}=0,3$

c. Bobot Tinggi $79-87$

$w 3=\frac{(4-3+1)}{(4-4+1)+(4-3+1)+(4-2+1)+(4-1+1)}=\frac{2}{10}=0,2$

d. Bobot Tinggi 88-97

$w 4=\frac{(4-4+1)}{(4-4+1)+(4-3+1)+(4-2+1)+(4-1+1)}=\frac{1}{10}=0,1$

Tabel 4.9 Bobot tinggi

\begin{tabular}{|r|c|l|c|c|}
\hline No & Kriteria Tinggi $(\mathrm{cm})$ & Nilai & Ranking & Bobot \\
\hline 1 & $5-8$ & 100 & 1 & 0,4 \\
\hline 2 & $9-12$ & 90 & 2 & 0,3 \\
\hline 3 & $13-16$ & 80 & 3 & 0,2 \\
\hline
\end{tabular}


URNAL EXPLORE IT!

Iol. 10 No. 1 - Juni 2018

I-ISSN 2086-3489 (Print)- e-ISSN 2549-354X (Online)

Ivaiable online at

nttp://jurnal.yudharta.ac.id/v2/index.php/EXPLORE-IT/

\begin{tabular}{|l|l|l|l|l|}
\hline 4 & $17-21$ & 70 & 4 & 0,1 \\
\hline
\end{tabular}

5. Menghitung kedekatan nilai antar variable

Tabel 4.10 kedekatan nilai variable umur

\begin{tabular}{|r|c|l|c|c|}
\hline No & Kriteria umur (bulan) & Nilai & Ranking & Bobot \\
\hline 1 & $6-9$ & 100 & 1 & 0,33 \\
\hline 2 & $10-13$ & 90 & 2 & 0,26 \\
\hline 3 & $14-17$ & 80 & 3 & 0,2 \\
\hline 4 & $18-21$ & 70 & 4 & 0,13 \\
\hline 5 & $22-24$ & 60 & 5 & 0,06 \\
\hline
\end{tabular}

${\text { Kedekatan } \text { variabel }_{12}=\frac{\text { Nilai variabel } 2}{\text { Nilai variabel } 1}}_{100}$

$K u_{11}=\frac{100}{100}=1$

$K u_{12}=\frac{90}{100}=0.9$

$K u_{13}=\frac{80}{100}=0.8$

$K u_{14}=\frac{70}{100}=0.7$

$K u_{15}=\frac{60}{100}=0.6$

Maka akan didapat tabel sebagai berikut :

Tabel 4.11 variabel umur

\begin{tabular}{|c|r|c|c|c|c|}
\hline & $\mathrm{U} 1$ & $\mathrm{U} 2$ & $\mathrm{U} 3$ & $\mathrm{U} 4$ & $\mathrm{U} 5$ \\
\hline $\mathrm{U} 1$ & 1 & 0.9 & 0.8 & 0.7 & 0.6 \\
\hline $\mathrm{U} 2$ & 0.9 & 1 & 0.89 & 0.78 & 0.67 \\
\hline $\mathrm{U} 3$ & 0.8 & 0.89 & 1 & 0.88 & 0.75 \\
\hline $\mathrm{U} 4$ & 0.7 & 0.78 & 0.88 & 1 & 0.86 \\
\hline $\mathrm{U} 5$ & 0.6 & 0.67 & 0.75 & 0.86 & 1 \\
\hline
\end{tabular}

Tabel 4.12 kedekatan nilai variabel berat

\begin{tabular}{|r|c|l|c|c|}
\hline No & Kriteria Berat & Nilai & Ranking & Bobot \\
\hline 1 & $5-8$ & 100 & 1 & 0,4 \\
\hline 2 & $9-12$ & 90 & 2 & 0,3 \\
\hline 3 & $13-16$ & 80 & 3 & 0,2 \\
\hline 4 & $17-21$ & 70 & 4 & 0,1 \\
\hline
\end{tabular}

${\text { Kedekatan } \text { variabel }_{12}}=\frac{\text { Nilai variabel } 2}{\text { Nilai variabel } 1}$

$K b_{11}=\frac{100}{100}=1$

$K b_{12}=\frac{90}{100}=0.9$

$K b_{13}=\frac{80}{100}=0.8$

$K b_{14}=\frac{70}{100}=0.7$

Maka akan didapat tabel sebagai berikut :

Tabel 4.13 kedekatan variabel berat

\begin{tabular}{|l|r|r|r|}
\hline B1 & B2 & B3 & B4 \\
\hline
\end{tabular}


URNAL EXPLORE IT!

Iol. 10 No. 1 - Juni 2018

I-ISSN 2086-3489 (Print)- e-ISSN 2549-354X (Online)

tvaiable online at

nttp://jurnal.yudharta.ac.id/v2/index.php/EXPLORE-IT/

\begin{tabular}{|l|l|c|c|c|}
\hline B1 & 1 & 0.9 & 0.8 & 0.7 \\
\hline B2 & 0.9 & 1 & 0.89 & 0.78 \\
\hline B3 & 0.8 & 0.89 & 1 & 0.88 \\
\hline B4 & 0.7 & 0.78 & 0.88 & 1 \\
\hline
\end{tabular}

Tabel 4.14 kedekatan tinggi

\begin{tabular}{|r|c|l|c|c|}
\hline No & Kriteria Tinggi & Nilai & Ranking & Bobot \\
\hline 1 & $5-8$ & 100 & 1 & 0,4 \\
\hline 2 & $9-12$ & 90 & 2 & 0,3 \\
\hline 3 & $13-16$ & 80 & 3 & 0,2 \\
\hline 4 & $17-21$ & 70 & 4 & 0,1 \\
\hline
\end{tabular}

${\text { Kedekatan } \text { variabel }_{12}=\frac{\text { Nilai variabel } 2}{\text { Nilai variabel } 1}}$

$K t_{11}=\frac{100}{100}=1$

$K t_{12}=\frac{90}{100}=0.9$

$K t_{13}=\frac{80}{100}=0.8$

$K t_{14}=\frac{70}{100}=0.7$

Maka akan didapat tabel sebagai berikut :

Tabel 4.15 variabel tinggi

\begin{tabular}{|r|r|c|c|c|}
\hline & \multicolumn{1}{|c|}{$\mathrm{t} 1$} & $\mathrm{t} 2$ & $\mathrm{t} 3$ & $\mathrm{t} 4$ \\
\hline $\mathrm{t} 1$ & 1 & 0.9 & 0.8 & 0.7 \\
\hline $\mathrm{t} 2$ & 0.9 & 1 & 0.89 & 0.78 \\
\hline $\mathrm{t} 3$ & 0.8 & 0.89 & 1 & 0.88 \\
\hline $\mathrm{t} 4$ & 0.7 & 0.78 & 0.88 & 1 \\
\hline
\end{tabular}

\subsubsection{Klasifikasi dengan Metode Neural Network}

4.1.2.1 Inisialisasi dengan bilangan acak kecil

Range nilai dari bilangan acak terkecil antara 0 sampai 1

Bobot umur

Tabel 4. 16 Bobot umur

\begin{tabular}{|r|c|l|r|}
\hline No & Kriteria umur (tahun) & Bobot & \multicolumn{1}{c|}{ Ranking } \\
\hline 1 & 6 & 0,1 & 1 \\
\hline 2 & 7 & 0,2 & 2 \\
\hline 3 & 8 & 0,3 & 3 \\
\hline 4 & 9 & 0,4 & 4 \\
\hline 5 & 10 & 0,5 & 5 \\
\hline 6 & 11 & 0,6 & 6 \\
\hline 7 & 12 & 0,7 & 7 \\
\hline 8 & 13 & 0,8 & 8 \\
\hline 9 & 14 & 0,9 & 9 \\
\hline 10 & 15 & 0,10 & 10 \\
\hline 11 & 16 & 0,11 & 11 \\
\hline 12 & 17 & 0,12 & 12 \\
\hline 13 & 18 & 0,13 & 13 \\
\hline 14 & 19 & 0,14 & 14 \\
\hline 15 & 20 & 0,15 & 15 \\
\hline 16 & 21 & 0,16 & 16 \\
\hline 17 & 22 & 0,17 & 17 \\
\hline 18 & 23 & 0,18 & 18 \\
\hline
\end{tabular}


URNAL EXPLORE IT!

Iol. 10 No. 1 - Juni 2018

I-ISSN 2086-3489 (Print)- e-ISSN 2549-354X (Online)

Ivaiable online at

nttp://jurnal.yudharta.ac.id/v2/index.php/EXPLORE-IT/

\begin{tabular}{|l|l|l|l|}
\hline 19 & 24 & 0,19 & 19 \\
\hline
\end{tabular}

Tabel 4.17bobot Berat

\begin{tabular}{|r|c|c|c|}
\hline No & Kriteria Berat $(\mathrm{kg})$ & bobot & Ranking \\
\hline 1 & 5 & 0,1 & 1 \\
\hline 2 & 6 & 0,2 & 2 \\
\hline 3 & 7 & 0,3 & 3 \\
\hline 4 & 8 & 0,4 & 4 \\
\hline 5 & 9 & 0,5 & 5 \\
\hline 6 & 10 & 0,6 & 6 \\
\hline 7 & 11 & 0,7 & 7 \\
\hline 8 & 12 & 0,8 & 8 \\
\hline 9 & 13 & 0,9 & 9 \\
\hline 10 & 14 & 0,10 & 10 \\
\hline 11 & 15 & 0,11 & 11 \\
\hline 12 & 16 & 0,12 & 12 \\
\hline 13 & 17 & 0,13 & 13 \\
\hline
\end{tabular}

Tabel 4.18bobot tinggi

\begin{tabular}{|c|c|c|c|}
\hline No & Kriteria Tinggi $(\mathrm{cm})$ & bobot & Ranking \\
\hline 1 & 61 & 0,1 & 1 \\
\hline 2 & 62 & 0,2 & 2 \\
\hline 3 & 63 & 0,3 & 3 \\
\hline 4 & 64 & 0,4 & 4 \\
\hline 5 & 65 & 5 & 5 \\
\hline 6 & 66 & 6 & 6 \\
\hline 7 & 67 & 7 & 7 \\
\hline 8 & 68 & 8 & 8 \\
\hline 9 & 69 & 9 & 9 \\
\hline 10 & 70 & 10 & 10 \\
\hline 11 & 71 & 11 & 11 \\
\hline 12 & 72 & 12 & 12 \\
\hline 13 & 73 & 13 & 13 \\
\hline 14 & 74 & 14 & 14 \\
\hline 15 & 75 & 15 & 15 \\
\hline 16 & 76 & 16 & 16 \\
\hline 17 & 77 & 17 & 17 \\
\hline 18 & 78 & 18 & 18 \\
\hline 19 & 79 & 19 & 19 \\
\hline 20 & 80 & 20 & 20 \\
\hline 21 & 81 & 21 & 21 \\
\hline 22 & 82 & 22 & 22 \\
\hline 23 & 83 & 23 & 23 \\
\hline 24 & 84 & 24 & 24 \\
\hline 25 & 85 & 25 & 25 \\
\hline 26 & 86 & 26 & 26 \\
\hline 27 & 87 & 27 & 27 \\
\hline
\end{tabular}


URNAL EXPLORE IT!

Iol. 10 No. 1 - Juni 2018

I-ISSN 2086-3489 (Print)- e-ISSN 2549-354X (Online)

Ivaiable online at

nttp://jurnal.yudharta.ac.id/v2/index.php/EXPLORE-IT/

\begin{tabular}{|l|l|l|l|}
\hline 28 & 88 & 28 & 28 \\
\hline 29 & 89 & 29 & 29 \\
\hline 30 & 90 & 30 & 30 \\
\hline 31 & 91 & 31 & 31 \\
\hline 32 & 92 & 32 & 32 \\
\hline 33 & 93 & 33 & 33 \\
\hline 34 & 94 & 34 & 34 \\
\hline 35 & 95 & 35 & 35 \\
\hline 36 & 97 & 0,36 & 36 \\
\hline
\end{tabular}

4.1.2.2 Hitung semua unit keluaran tersembunyi pada layer $Z_{n e t j}=V 0 j+\sum_{j=1}^{p} x_{1} v_{i j}$

Umur 6 bulan mempunyai pembangkit bilangan acak terkecil 0,6

Berat $5,7 \mathrm{~kg}$ mempunyai pembangkit bilangan acak terkecil 0,1

Tinggi $61,2 \mathrm{~cm}$ mempunyai pembangkit bilangan acak terkecil 0,1

4.1.2.3 Hitung keluaran semua jaringan di Unit $\mathrm{Y}_{\mathrm{k}}(\mathrm{k}=1 \ldots \mathrm{m}) Y_{\text {netk }}=w 0 j+\sum_{k=1}^{m} z_{j} w_{j k}$ Ini menghitung semua jenis layer inputan sample pada data training

Data training ke-1

\begin{tabular}{|c|c|c|c|c|c|}
\hline & & (z1) & (z2) & (z3) & jumlah \\
\hline & & 0.01 & 0.01 & 0.01 & \\
\hline (x1) & 0.01 & 0.0001 & 0.0001 & 0.0001 & 0.0003 \\
\hline (x2) & 0.01 & 0.0001 & 0.0001 & 0.0001 & 0.0003 \\
\hline (x3) & 0.01 & 0.0001 & 0.0001 & 0.0001 & 0.0003 \\
\hline \multicolumn{5}{|c|}{ Jumlah } & 0.0009 \\
\hline
\end{tabular}

Data training ke-2

\begin{tabular}{|l|c|c|c|c|c|}
\cline { 3 - 6 } \multicolumn{1}{c|}{} & $(\mathrm{z} 1)$ & $(\mathrm{z} 2)$ & $(\mathrm{z} 3)$ & jumlah \\
\cline { 3 - 6 } & & 0.01 & 0.02 & 0.03 & \\
\hline$(\mathrm{x} 1)$ & 0.01 & 0.0001 & 0.0002 & 0.0003 & 0.0006 \\
\hline$(\mathrm{x} 2)$ & 0.02 & 0.0002 & 0.0004 & 0.0006 & 0.0012 \\
\hline$(\mathrm{x} 3)$ & 0.03 & 0.0003 & 0.0006 & 0.0009 & 0.0018 \\
\hline \multicolumn{5}{|c|}{ Jumlah } & \\
\hline
\end{tabular}

Data training ke-3

\begin{tabular}{|l|c|c|c|c|c|}
\cline { 3 - 6 } \multicolumn{1}{|c|}{} & $(\mathrm{z} 1)$ & $(\mathrm{z} 2)$ & $(\mathrm{z} 3)$ & jumlah \\
\cline { 3 - 6 } & & 0.01 & 0.03 & 0.05 & \\
\hline$(\mathrm{x} 1)$ & 0.01 & 0.0001 & 0.0003 & 0.0005 & 0.0009 \\
\hline$(\mathrm{x} 2)$ & 0.03 & 0.0003 & 0.0009 & 0.0015 & 0.0027 \\
\hline$(\mathrm{x} 3)$ & 0.05 & 0.0005 & 0.0015 & 0.0025 & 0.0045 \\
\hline \multicolumn{5}{|c}{ Jumlah } & 0.0081 \\
\hline
\end{tabular}

4.1.2.4 Tabel Nilai Ketetapan Standar Deviasi

Tabel 4.19 Keseluruhan Gizi anak

Status Gizi

Klinis

Antropometri

(BB/TB)

Nilai 
I-ISSN 2086-3489 (Print)- e-ISSN 2549-354X (Online)

tvaiable online at nttp://jurnal.yudharta.ac.id/v2/index.php/EXPLORE-IT/

\begin{tabular}{|l|l|l|l|}
\hline & & & Ketetapan \\
\hline Gizi Buruk & $\begin{array}{l}\text { Tampak sangat Kurus } \\
\text { dan atau odema pada } \\
\text { kedua pungung kaki } \\
\text { sampai seluruh tubuh }\end{array}$ & $<-3$ SD & 0.0001 \\
s.d & & 0.0225 \\
\hline Gizi Kurang & Tampak Kurus & $\geq-3$ SD - <-2SD & 0.226 s.d \\
& & -2 SD - + 2 SD & 0.1225 \\
\hline Gizi Baik & & & s.d \\
& & $>+2$ SD & 0.2116 \\
\hline Gizi Lebih & & & 0.2117 \\
& & & \\
\hline
\end{tabular}

4.1.2.5 Tabel Hasil perhitungan Algoritma Neural Network Backpropotagion adalah sebagai berikut :

Tabel 4.20 Hasil Perhitungan Neural Network

\begin{tabular}{|c|c|c|c|c|}
\hline No & $\begin{array}{c}\text { Umur } \\
\text { (Bulan) }\end{array}$ & $\begin{array}{c}\text { Berat } \\
\text { Badan } \\
\text { (Kg) }\end{array}$ & $\begin{array}{c}\text { Tinggi } \\
(\mathbf{c m})\end{array}$ & Hasil \\
\hline 1 & 6 & 5.7 & 61.2 & 0.0009 \\
\hline 2 & 7 & 5.9 & 62.7 & 0.0025 \\
\hline 3 & 8 & 6.2 & 64 & 0.0081 \\
\hline 4 & 9 & 6.4 & 65.2 & 0.0121 \\
\hline 5 & 10 & 9.2 & 73.3 & 0.0529 \\
\hline 6 & 11 & 13 & 81.5 & 0,1296 \\
\hline 7 & 12 & 6.9 & 68.6 & 0,0289 \\
\hline
\end{tabular}

\subsubsection{Perhitungan Gizi anak dengan Neural Network}

Dengan perhitungan neural Network untuk menentukan klasifikasi dengan tabel sebagai berikut :

\footnotetext{
Berikut ini adalah pengklasifikasian masing-masing tabel per status gizi dengan standart ketentuan sebagai berikut :

a. Tabel Gizi buruk

b. Tabel Gizi kurang

c. Tabel Gizi Baiak

d. Tabel Gizi Lebih
}

\subsection{Validasi dan Hasil Penelitian}

Untuk validasi hasil penelitian, digunakan cross validation, yaitu dengan membagi 133 dataset ke dalam 10 bagian, yaitu sembilan bagian dataset training sebanyak $90 \%$ atau 120 dan satu bagian data testing sebanyak $10 \%$ atau 13.

\subsection{Hasil Eksperimen dan Pengujian Model}

Pada tahapan ini akan membahas hasil dari experiment yang telah dilakukan oleh peneliti, dimana peneliti sudah melakukan penelitian pada data set standarisasi gizi pada anak, di usia 6 bulan sampai dengan 24 bulan. Pada dua metode data mining tersebut, baik NeuralNetwork maupun $K$-Nearest Neighbor $(K-n n)$. Metode Neural Network telah melakukan sebanyak 10 Validation, dan Untuk K-NN, telah melakukan K sebanyak 25 di 100 Validation. Rincian hasil akan dibahas dimulai dari Neural Network setiap 10 Validation.

\subsection{Hasil Uji Validasi menggunakan Metode K-NN}

Peneliti telah melakukan validation hingga ke-100, dengan K sampai 25, K disini harus ganjil, karena pada metode K-NN, dengan $\mathrm{K}$ ganjil maka akan diketahui kedekatan dari data set pada saat perbandingan yang lebih dominan. Untuk lebih detailnya perhatikan table akurasi dan jumlah $\mathrm{K}$ yang sudah memiliki akurasi pada setiap masing-masing validation tersebut.

Table 4.21 Hasil Validation 2 dengan K 1 sampai 25 
URNAL EXPLORE IT!

Iol. 10 No. 1 - Juni 2018

I-ISSN 2086-3489 (Print)- e-ISSN 2549-354X (Online)

Ivaiable online at

nttp://jurnal.yudharta.ac.id/v2/index.php/EXPLORE-IT/

\begin{tabular}{|c|c|c|}
\hline Validation & $\mathrm{K}$ & Accuracy \\
\hline 2 & 1 & $77,44 \%$ \\
\hline 2 & 3 & $70,68 \%$ \\
\hline 2 & 5 & $72,93 \%$ \\
\hline 2 & 7 & $67,67 \%$ \\
\hline 2 & 9 & $63,91 \%$ \\
\hline 2 & 11 & $62,41 \%$ \\
\hline 2 & 13 & $60,90 \%$ \\
\hline 2 & 15 & $60,15 \%$ \\
\hline 2 & 17 & $59,40 \%$ \\
\hline 2 & 19 & $57,14 \%$ \\
\hline 2 & 21 & $54,89 \%$ \\
\hline 2 & 23 & $51,13 \%$ \\
\hline 2 & 25 & $51,88 \%$ \\
\hline
\end{tabular}

Dari validation 2 dengan K 1 sampai 25 dengan hitungan dalam bentuk ganjil, didapat akurasi tertinggi pada K ke-1, jumlah akurasi 77,44\%. Dan akurasi terkecil 51,13\% K ke-23.

Hasil di atas sesuai dengan proses yang ada, dimana akurasi yang paling tinggi terdapat pada K 3 dan validation kelipatan dari 10, dengan jumlah akurasi 95,49\% pada validation ke 20,30, 50, 60,80, 90 dan 100.

Tabel 4.22 Konfusion Matrik sebagai berikut

\begin{tabular}{|l|c|c|c|c|}
\hline \multicolumn{1}{|c|}{ TRUE } & Gizi Buruk & Gizi Kurang & Gizi Baik & Gizi Lebih \\
\hline Gizi Buruk: & 19 & 1 & 0 & 0 \\
\hline Gizi kurang: & 0 & 35 & 1 & 0 \\
\hline Gizi Baik: & 0 & 1 & 55 & 1 \\
\hline Gizi Lebih: & 0 & 1 & 1 & 18 \\
\hline
\end{tabular}

\subsection{Hasil Uji Validasi menggunakan Neural Network}

Table 4.23 Hasil Validation 2 sampai 10

\begin{tabular}{|c|c|}
\hline Validation & Accuracy \\
\hline 2 & $96,99 \%$ \\
\hline 3 & $97,74 \%$ \\
\hline 4 & $95,49 \%$ \\
\hline 5 & $96,24 \%$ \\
\hline 6 & $93,98 \%$ \\
\hline 7 & $89,47 \%$ \\
\hline 8 & $92,48 \%$ \\
\hline 9 & $91,73 \%$ \\
\hline 10 & $92,48 \%$ \\
\hline
\end{tabular}

Metode Neural Network yang dicari dengan cara X-Validation, yang tahap awal dilakukan validation dari 2 sampai 10, dimana hasilnya memiliki rata-rata validation di atas 90\%. Akurasi yang paling tinggi berada pada validation ke- 3 , dengan jumlah akurasi $97,74 \%$ dan paling kecil pada validation ke- 7 dengan akurasi 89,47\%.

Confusion Matrix untuk Neural Network pada validation ke-3 adalah sebagai berikut

Tabel 4.24 Konfusion Matrik

\begin{tabular}{|l|l|l|l|l|}
\hline True & Gizi Buruk & Gizi Kurang & Gizi Baik & Gizi Lebih \\
\hline Gizi Buruk & 19 & 1 & 0 & 0 \\
\hline Gizi Kurang & 0 & 36 & 1 & 0 \\
\hline Gizi Baik & 0 & 0 & 56 & 0 \\
\hline Gizi Lebih & 0 & 1 & 0 & 19 \\
\hline
\end{tabular}


Dari kedua metode tersebut yaitu, Neural Network dan K-Nearest Neighbor (K-NN), dimana akurasi tertinggi pada Neural Network adalah $97,74 \%$ pada validation ke-3 dan K-NN akurasi yang paling tinggi 95,49\% pada validation rata-rata kelipatan dari 10 .

\subsection{Kesimpulan}

\section{PENUTUP}

Kesimpulan dari penerapan 2 metode data mining yang klasifikasi tersebut, yaitu Neural Network dan K-Nearest Neighbor (K-NN) dalam mencari akurasi terbaik pada standarisasi gizi anak pada Puskesmas Paiton Probolinggo tersebut, ada kesimpulan yang didapat. Baik metode Neural Network ataupum KNearest Neighbor (K-NN) akurasi yang paling tinggi ada pada K ke-3 pada metode K-Nearest Neighbor (K$\mathrm{NN})$ akurasi dan validation ke-3 pada metode Neural Network. Jadi memiliki kesamaan dalam pemprosesan data set pada kedua data minig tersebut. Dan setelah melakukan beberapa uji coba, dimana metode Neural Network validation 2 sampai 70, angka 70 dianggap cukup karena melihat dari perkembangan tingkat akurasiannya dimana makin tinggi akurasinya, maka akan makin kecil akurasi yang didapat. Akurasi tertinggi pada metode Neural Network adalah 97,74\% pada validation ke-3. Dan untuk metode K-NN, akurasi yang paling tinggi adalah 95,49\% dari validation rata-rata kelipatan dari 10 dan pada K ke-3. Jadi metode akurasi dari kedua metode tersebut yang memiliki akurasi yang paling tinggi adalah Neural Network dengan akurasi 97,74\% pada validation ke-3.

\subsection{Saran}

1. Berdasarkan hasil penelitian di atas untuk pemilihan berdasarkan klasifikasi, sebaiknya menggunakan metode neural network dengan backpropagation karena memiliki tingkat keakurasian yang lebih baik dibandingkan dengan metode k-NN

2. Sebaiknya data set yang digunakan lebih banyak lagi agar memiliki tingkat akurasi yang lebih baik.

\section{Daftar Pustaka}

[1] American Academy of Pediatrics, Use of Soy Based Formulas in Infant Feeding., 2008.

[2] dokterindonesiaonline.com, Jumlah takaran dan jenis makan minum bayi usia 0-12 bulan., 2008.

[3] Badan Perencanaan Pembangunan Nasional, Rencana Aksi Nasional Pangan dan Gizi 2006-2010. Jakarta, 2007.

[4] Ariani, Wilayah Rawan Pangan dan Gizi Kronis di Papua, Kalimantan Barat dan Jawa Timur. Bogor: Pusat Analisis dan Kebijakan Pertanian Departemen Pertanian, 2007.

[5] Malik, Gizi Buruk Tewaskan 3,5 Juta Balita Per tahun.: www.lifestyle.okezone.com, 2008.

[6] Irwandy, Sulawesi Selatan Daerah Penghasil Pangan dan Gizi Buruk. Makassar: Program Studi Kesehatan Masyarakat Universitas Hasanudin, 2007.

[7] Clara, Makanan Untuk Bayi Cerdas dan Menjaga Perkembangan Otak Bayi.: mutiarabijaksana.com, 2014.

[8] Mentri Kesehatan, Keputusan Menteri Kesehatan Republik Indonesia., 2010.

[9] Wu Noerlina, Perancangan Sistem Informasi Berbasis Object Oriented. Jakarta, Indonesia: MitraWacana Media., 2009.

[10] Saputra, Wahyu S. J., Arif Rahman Sujatmika, and Agus Zainal Arifin, eleksi Fitur Menggunakan Random Forest Dan Neural Network. Surabaya, Indonesia: Electronic Engineering Polytechnic Institute, 2011.

[11] Susilowati, Pengukuran Status Gizi dengan Antropometri Gizi. Cimahi, Indonesia, 2008.

[12] Kusrini and Ehha T. Luthfi, Algoritma Data Mining. Yogyakarta: Andi, 2009.

[13] Eko Prasetyo, Data Mining Konsep dan Aplikasi Menggunakan Matlab. Yogyakarta: Andi, 2012.

[14] James Immanuel Luke and Suharjito, "Data Mining Tweet Promosi Produk dan Jasa Secara Otomatis dengan Menggunakan Algoritma Naive Bayes untuk Meningkatkan Engagement Followers Twitter," in Binus University, 2015.

[15] A'ang Subiyakto, "Penggunaan Algoritma Klasifikasi dalam Data Mining," in Program Studi Sistem Informasi Fakultas Sains dan Teknologi UIN Jakarta, Jakarta, 2008.

[16] Wu X and Kumar V. Top Ten Algorithms in Data Mining,. New Yurk : CRC Press, 2009.

[17] Han J and Kamber M, Data Mining: Consept and Techniques. New York: Morgan Kaufmann, 2006.

[18] Goujon G and Jianhong W. Chaoqun, Data Clusterin : Theory, Algorithms, and Applications. Virginia: ASA, 2007.

[19] Budi Santosa, Data Mining Teknik Pemanfaatan Data untuk Keperluan Bisnis. Yogyakarta, Indonesia: Graha Ilmu, 2007.

[20] F Gorunescu, Data Mining: Concepts Models, and Techniques.: Springer, 2011. 
URNAL EXPLORE IT!

Iol. 10 No. 1 - Juni 2018

I-ISSN 2086-3489 (Print)- e-ISSN 2549-354X (Online)

tvaiable online at

nttp://jurnal.yudharta.ac.id/v2/index.php/EXPLORE-IT/

[21] Bramer and Max, Principles of Data Mining. London: Springer, 2007. 